\title{
Fides Quaerens Corporalitatem: Perspectives on liturgical embodiment
}

J H Cilliers

(University of Stellenbosch)

\section{ABSTRACT \\ Fides Quaerens Corporalitatem: Perspectives on liturgical embodiment}

In the light of a number of paradigm shifts that have taken place in practical theological methodology, this article proposes an integrative approach that takes the fundamental role of embodiment into account. A brief discussion of the theological understanding of embodiment is followed by a reflection on certain liturgical implications, inter alia liturgical embodiment as immediate participation; as multi-sensory interpretative act; and as broken presence and celebrated absence.

\section{PRACTICAL THEOLOGICAL PARADIGM SHIFTS}

During the course of its history practical theological methodology has undergone some major paradigm shifts. Since the times of Schleiermacher (1989:133), who has been hailed as the father of practical theology, the focus has been strongly fixed on selfconsciousness, namely, the experience of faith and its inexpressible feeling of dependency on God ("schlechthinniges Abhängigkeitsgefühl von Gott"). With this also came a new interest in the expertise (technè) of ministry. This in turn reopened the question whether practical theology is a normative science or a phenomenological-empirical one, also in light of the development of the humanities (humanioria) with their interdisciplinary trends and strong behaviourist interests.

These developments could also be described as a movement away from a clerical and ecclesiological framework to an emphasis on praxis, which incorporates concepts such as liberation, communication, action, change and transformation (cf Louw 2001:91). Broadly speaking, the following distinctions indicate some of the paradigm shifts in practical theological methodology:

- $\quad$ Fides quaerens intellectum (faith in search of understanding): here the intention is to understand, interpret and proclaim the 
revelation of God in a logical and cognitive way, especially within an ecclesiological context. The emphasis is on teaching.

- $\quad$ Fides quaerens verbum (faith in search of words): a narrative and non-directive approach, complemented by fitting modes of communication and discourse. The emphasis is on the act of expression.

- $\quad$ Fides quaerens actum (faith in search of acts): the emphasis is on stronger integration of theory and practice, liberation, transformation and on ways of doing practical theology (cf the title of Dingemans's book: Manieren van doen 1996). The focus is on the development of skills.

- $\quad$ Fides quaerens imaginem (faith in search of images; symbolic expression): although not meant to oppose ${ }^{1}$ the abovementioned emphases, it brings a new dimension into play, namely what has been called aesthetic reason or aesthetic hermeneutics (cf Van Erp 2003:15; also Louw 2001:91). The emphasis falls on the art of imagination and creative expression.

- Fides quaerens visum (faith in search of concrete visualisation): linked to the previous distinction, but refining it. The intention is to aid people to discern traces of God's presence by means of visual and virtual realities. The role of modern technology (internet, mass media, etc) is brought into consideration (cf Louw 2008:20, 74).

- $\quad$ Fides quaerens spem (faith in search of hope): the emphasis lies on the understanding and experiencing of meaning, as well as the means to foster and facilitate this through the liturgy, pastoral care, preaching, etcetera. The significance of eschatology plays an important role in this regard.

In this paper I want to propose a further distinction that might prove to be helpful in our quest for a practical theological methodology, and which may hopefully serve as an integrative approach to all of

1 Kant did evaluate the aesthetical as a type of opposite of the rational. And yet he and other classic authors like Schiller and Baumgarten did not deny the importance of aesthetics in our search for truth, knowledge and meaning (for an extended discussion of the importance of Kant for our understanding of aesthetics, cf Begbie 2003:187-191; also Orth 2003:250). 
the abovementioned distinctions. I am of the opinion that the existentialia which are brought into play in the different paradigms (intellect, language, acts, hope, visualisation and imagination) can only be understood within the paradigm of embodiment. Thus:

- Fides quaerens corporalitatem (faith in search of embodiment): a holistic approach, taking the embodiment of humans seriously, inter alia also as the address of revelation. Our bodies are central to what we perceive and experience, also in terms of our relationship with God. It is the prime locus of God's presence with us. This understanding of embodiment is of specific importance for the liturgy, as it entails the notions of contextualisation, immediacy, encountering, embracement, communality, radicalisation and concreteness (cf the discussion below in 3).

This article will attend briefly to the theological background of embodiment, followed by some implications for liturgical practices, especially in the African context.

\section{EMBODIMENT: A THEOLOGICAL REFLECTION}

Postmodern people, especially young people, are rediscovering their bodies. In an era when many traditional "objective" anchors for orientation, as well as referential frameworks for understanding identity, are questioned and indeed rejected, the body, as well as its adornment, well-being and nourishing, has become important. In a sense the body has become a type of anchoring point in itself; it has become the public and social expression of the fact that people are somebody, and not nothing. For young people, the phenomenon of fashion is, for instance, presently much more than just an expression of the spirit of the time, but rather acts as a semi-religious ritual which must aid the understanding of identity. The church would be unwise not to take cognisance of these facts (Sellmann 2003:259).

The notion of embodiment (or body-liness), however, is not something new. During certain periods of church history, for instance, the profound theological background of embodiment was understood and debated, although it was also grossly neglected and even downplayed during other periods. Lukken (1990:6-7) refers to the anthropological turn that theology has taken since the sixties (also bringing the relationship between body-liness and liturgy back into the spotlight), and which, according to him, operates with the 
Semitic anthropology of scripture, rather than with a GreekHellenistic understanding of human beings.

With the incarnation of Christ the meaning of body-liness in God's revelation is radicalised (Lukken 1990:16). God does not reveal Himself to us outside the framework of our body-liness - of that Christ himself is the embodied proof. But this is radicalised even further with the outpouring of the Holy Spirit. The Spirit is not a fleeting, amorphous identity, but rather is poured out on all flesh (Acts 2). The indwelling of the Spirit (inhabitatio Spiritus Sancti Internum) emphasises the body-liness of God's revelation - of that the church is now the embodied proof.

Lukken (1990:18-19) points out the interesting fact that the Eastern tradition seems to focus more on the "already" of the inhabitatio spiritus sancti, while the "not yet" dominates the Western tradition. This could partly explain why the former allows more space in the liturgy for bodily expression and enactment, and the latter seems to be lacking in exactly this regard. We will return to this discussion in 3 below.

The definition that Bonhoeffer (1998:33) has given for the church as community seems to be of profound relevance here: Christus als Gemeinde existierend (Christ existing in the form of the congregation). According to Bonhoeffer, God must be praised "for the bodily presence of the other Christian. The prisoner, the sick person, the Christian living in the Diaspora and so on recognizes in the nearness of a fellow Christian a physical sign of the gracious presence of the Triune God” (cf Vosloo 2006:30).

God's (bodily) presence amongst us seems to entail at least two dimensions, namely divine self-presentation (even divine disclosure) and human re-presentation. The Spirit has body (or perhaps we should say: the Spirit is body), and without this body it would be difficult, if not impossible, to experience God's presence with us. The Spirit is God's embodied accommodation to created reality, and this can be experienced in and through the church, the latter being Christ existing in the form of the congregation. God's embodiment amongst us is therefore an accommodation to our limitations and peculiarities, but not an eradication of them. Put in the abovementioned terms, God's embodiment does not nullify our endeavours to believe in terms of intellectum, verbum, actum, 
imaginem, visum and spem, but in fact incorporates all of this. His presence amongst us takes on a real corporeal character.

The fact that God speaks to us in anthropomorphic terms and language structures further emphasises His passion to accommodate Himself to us. Calvin wrote at length about this: "Because our weakness cannot reach his height, any description which we receive of Him must be lowered to our capacity in order to be intelligible. And the mode of lowering is to represent Him not as He really is, but as we conceive of Him" (Calvin Inst 1/17/13; also 1/11/3; 2/11/13; 2/16/2).

Within this theological framework the body as such becomes the interpretative action of human beings. We do not have bodies; we are bodies (Van der Leeuw 1949:9). Certain senses or capabilities cannot be crystallised as being the primary or most basic. It is not feasible to abstract a core (for instance, cognitive, or verbal, or manual, or optical, etc) and elevate this as being the apex of humanity or the sole interpretative medium. We are bodies, with all of our senses and capabilities being part of a complex whole. God reveals Himself to, and through, all of our senses, for the simple reason that we are bodies. For the Apostle Paul the body (soma) simply expresses the character of created humankind - that is, as embodied existence. Dunn (1998:61) concludes: "It is precisely as embodied, and by means of this embodiment, that the person participates in creation and functions as part of creation".

But what body are we talking about here? We have already referred to the postmodern obsession with the body, focusing on its adornment, well-being and health. But the way in which God is present in this world, as "Christus als Gemeinde existierend", takes on a different, alternative form. According to Hauerwas (1998:22), "The community, in its corporate life, is called to embody an alternative order that stands as a sign of God's redemptive purposes in the world".

Bonhoeffer has already warned against what he calls "a vitalistic absolutising of life", which has got to do with the mechanisation of life - when the individual is understood solely in terms of his or her usefulness (cf Vosloo 2006:24). The church, however, exists within a different form, stemming from a different Christ- and therefore life-image. It adheres to an alternative understanding of humans' being-functions, as expressed in 
embodiment. These being-functions are not about usefulness in the sense of purpose-driven success and market-orientated output, but about "uselessness" in the sense of sacrifice and service. Bonhoeffer (2002:143), being bodily incarcerated at the time, wrote movingly about this Christ-image:

Who is God? Not in the first place a general belief in God, in his omnipotence, etc. That is not a genuine experience of God, but part of a prolongation of the world. Encounter with Jesus Christ. The experience that a reversal of all human life is given in the fact that "Jesus is there only for others". His "being there for others" is the experience of transcendence. It is only this freedom from himself, this "being there for others", even to death, that is the source of his omnipotence, omniscience, and omnipresence.

This type of body clearly differs fundamentally from the idolised body of contemporary society. It indeed deconstructs the myth that our bodies are or should be perfect (omnipotent, omniscient, and omnipresent). It is a body given away for the sake of others, broken for the healing of others. It represents an all-encompassing reversal of our understanding of body-liness.

Caputo has made some striking differentiations between what he calls "philosophy's body", or le corps propere; and "Jewgreek bodies" or le corps impropere - reminiscent of the Apostle Paul's combination of elements of Hebrew and Greek anthropology into a new synthesis (cf Dunn 1998:72). Caputo (1993:194, 207) describes le corps impropere as "flesh", and elucidates as follows:

Philosophy's body - from Plato and Aristotle to MerleauPonty - is an active, athletic, healthy, erect, white male body, sexually able and unambiguously gendered, wellborn, well-bred, and well-buried, a corpus sanum cut to fit a mens sana in the felicity of being-in-the-world and mundane intentional life. But the bodies of Polyneices, Isaac, and Shulamith, of the lepers and the man with the withered hand, are disfigured, diseased, unburied, sacrificial, and ashen bodies... they fall outside the classical paradigm of propriety and comely form... The flesh is not the eye that sees but the eye that is hollowed out by hunger; that is blinded by injury or disease or 
genetic fault; the cancerous eye that submits to the invasive knife of the surgeon... Not the eye of Cézanne but the eye of a man born blind. The flesh is not the ear that hears but the ear in pain that rattles with the confusion of indiscernible sounds, the site of vertigo and nausea. The flesh is the ear of the man born deaf... The flesh is not the tongue which tastes but the tongue cut out by the torturer's or surgeon's knife, the tongue which is twisted or tied by a genetic defect....

This distinct understanding of body influences our understanding of liturgy in a profound way. We now attend to this.

\section{EMBODIMENT: LITURGICAL IMPLICATIONS}

\subsection{Liturgical embodiment as immediate participation}

The body forms the basic structure of our existence. It is therefore unthinkable that the liturgy - also understood as leitourgia, as the liturgy of life - does not create spaces for immediate, corporeal participation. In the Reformed tradition the immediacy of faith is of the utmost importance, namely, faith not mediated through priests or church officials, but directly, immediately between believers and God. There is nothing more immediate than our bodies. To construct a liturgy foreign to this would in fact be an abstraction from life, would construe a form of dichotomy or liturgical spiritualisation. As a matter of principle the latter is impossible for, as we have noted before, Spirit is body.

We participate with our bodies, or we do not participate at all. Perhaps the metaphor of an orchestra might be helpful in this regard; anyone who has watched the musicians perform knows that they do so with the totality of their corporality. Mind, eyes, ears, fingers, feet - all are taken up in the performance of the music. They literally embody the music. To participate in the liturgy is to embody faith; it is fides quaerens corporalitatem. It would be quite ludicrous to "be part" of the liturgy as an outsider, as if you were only part of the audience listening to the orchestra, or alone at home listening to the recording - at least if you confess to be intrinsically incorporated into this liturgy (cf 1 Cor 12). 
Generally speaking, expression via the body ${ }^{2}$ takes place more spontaneously in African worship services than is normally the case in Western liturgies. Africans have an almost natural or instinctive bodily awareness, particularly also in a communal context. In the socalled Independent African Churches, the Dutch Reformed Church in Africa and in some congregations of the Uniting Reformed Church in Southern Africa, the African culture (spirituality) of bodily and sensory expression is clearly illustrated in the liturgy. Music with rhythmical musical instruments, dance and bodily movements all form part of the pulsating expression of faith.

One could also say that it is a corporeal expression of the African spirituality of togetherness, called Ubuntu. Briefly put, Ubuntu has been defined as the belief that one is a human being through others ("I am because you are"). The term Ubuntu comes from the Zulu and Sotho versions of a traditional African aphorism, often translated as "A person is a person through other persons": Umuntu ngumuntu ngabantu. Motho ke motho ka batho. It articulates a basic respect and compassion for others. As such, it is both a factual description and a rule of conduct or social ethic, both descriptive and prescriptive (Ramose 1999:49; Shutte 1993:46).

Ubuntu defines the individual in terms of relationships. It represents a sort of web of reciprocal relations in which subject and object are indistinguishable. Therefore not: "I think, therefore I am”, but rather "I participate, therefore I am". In participation lies identity. This is particularly true of African worship services. Their very core consists of corporeal engagement and participation.

Small wonder then that dancing is so important in African worship services. It expresses, in a dynamic and corporeal way, the essence of participatory identity. Africans could rightly say: "I dance (with you), therefore I am”. Africans dance themselves into existence, together. As McGann (2002:19) puts it:

2 In African anthropology there is no such thing as a "soul" that is something separate from the body. Body simply is soul, and soul body. Therefore African worship services, with their emphasis on body, can also be essentially described as "soulful". Indeed, "soul" is a primary aesthetic criterion for the way that persons participate (bodily) in worship (cf McGann 2002:7). 
In contrast to Descartes' "I think, therefore I am”, a Black African perception might be summarised, "I am, I dance the other”. In Black Africa, you dance because you feel. And to dance is a verb with precisely that objectcomplement; you never dance without dancing something or someone. Now, to dance is to uncover reality, to recreate, to fill one's being with vital force, to live a fuller life, to BE, which, after all, is the highest mode of knowing.

Of course, not all liturgies need to be filled with (literal) dancing. But it remains a powerful metaphor ${ }^{3}$ to describe the essence of immediate, corporeal participation in worship. But corporeal participation and expression are but one layer of liturgical embodiment. It leads as of necessity to the corporeal, namely to multi-sensory experience, underlining a holistic epistemology.

\subsection{Liturgical embodiment as multi-sensory, interpretative act}

In our theological reflection we have already stated that the theology of incarnation and inhabitation sanctifies life and specifically bodyliness as the locality within which revelation takes place. It could be said that this represents a sacramental world view. The incarnation of Christ and the indwelling of the Spirit underline the integration of life, and therefore all processes of integration or reintegration in the light of the Christ- and Pentecost-event become sacramental, mediating life (salvation). Incarnation and inhabitation form the theological frameworks within which the sacredness of embodiment could be understood.

McFague has forcefully argued that the world as such could metaphorically be understood as being God's Body. For her, this implies that "the action of God in the world is similarly interior and caring... Furthermore, the model of the world as God's body suggests that God loves bodies: in loving the world, God loves a body. Such a notion is a sharp challenge to the long antibody, antiphysical, anti-matter tradition within Christianity" (1987:37, 47).

3 Research has shown that dance also represents a particular expression of God's presence for the aboriginal people (Aborigines) of Australia: when they dance, God is no longer past time, but realistic presence (Jordan and Tucker 2002:308). 
The notion of embodiment has decisive implications for our understanding of epistemology. Truth becomes a multi-dimensional and multi-sensory experience and event. It is not a neatly defined and eternal fact, but is given through a holistic experience (observation) of life as such. This is also not alien to African thought. According to McGann (2002:8)

....all aspects of creation can be channels of God's grace. In contrast to the God often projected in Christian ritual one who requires reserve, decorum and propriety - Black people have envisioned a God who is a lover of singing and dancing, of human expressiveness, of color and dress. Worship that is truly human and truly Godlike requires a broad sensorium that reflects the "fertile genius" of God exhibited in creation.

To receive this sacramental mediation of life through all aspects of creation requires the use of all the senses. Therefore African worship services have a natural tendency towards dramatic structuring and artistic expression. Whilst Western, and particularly Protestant, liturgies are still to some extent influenced by a spirit of Puritanism, with a denial of corporality, a distrust in anything that could mediate pleasure through the senses, a fear of emotion, etcetera, African liturgies engage all the senses (ocular, oral, aural, etc) in a holistic aesthetics of observation and experience. Seeing, smelling, feeling and tasting the Word are not strange experiences to African spirituality and therefore African worship services. A sort of reciprocal enrichment takes place in a cross-reference of senses: "There is a natural tendency for interpenetration and interplay, creating a concert or orchestration in which the ear sees, the eye hears, and where one both smells and tastes color, wherein all the senses, unmuted, engage in every experience" (McGann 2002:1819).

This could rightly be called a multi-sensory, corporeal interpretative act. It would be a justified question to ask whether such an act indeed takes place in the typical Protestant worship service. It has often been said that Protestant worship services are sometimes so inclined to be centred on the act of (cognitive) preaching, that it deteriorates into a lecture with mere liturgical addenda (Meyer-Blanck 2005:134). One could probably describe many Protestant services, even today, in the words of J F White: "the 
most cerebral of the Western traditions... prolix and verbose... overwhelmingly cerebral" (1989:58; cf also Wheeler 2003:348).

In part, this focus on preaching and listening, on teaching and receiving, could be ascribed to a certain understanding of sola Scriptura and the confession that the Spirit works through the Word. According to Wepener, "The Reformatory saying Praedicatio verbi Dei est verbum Dei is still mainly and exclusively interpreted as the preaching being an auditory medium, and something like See/ Smell/ Feel/ Taste verbi Dei est (also) verbum Dei, is largely downplayed" (Wepener 2002:13; cf also Cilliers 2007:63).

In the African context, however, it is unthinkable to operate with a reduced or minimalised understanding of anthropology in worship services. The body itself becomes the space, tool and medium for interpretation; as body it constitutes the hermeneutical text for life. One is reminded of the classic discernment of Romano Guardini (1997:60) in regard to the body as interpretative act:

The people who really live by the liturgy will come to learn that the bodily movements, the actions, and the material objects which it employs are all of the highest significance. It offers great opportunities of expression, of knowledge, and of spiritual experience; it is emancipating in its action, and capable of presenting a truth far more strongly and convincingly than can the mere word of mouth.

Indeed, the body interprets. But, once again, what body?

\subsection{Liturgical embodiment as broken presence and celebrated absence}

We have noted before that a choice for the body or body-liness does not necessarily indicate a choice for the gospel of the embodied God. In society all emphasis is placed on the beauty, nurturing and wellbeing of the body. Men's health, women's fashions and an obsessive gym culture seem to be the order of the day. In the mass media, through advertisement and other visual bombardments the perfect body is continuously idolised. The (perfect) body reigns supreme.

A theological understanding, however, brings another type of body into view - a broken body that can be healed by another broken Body. Caputo (2006:131) articulates this movingly: 
... by flesh let us signify everything that is both vulnerable or able to be wounded, which means bent, cut, lacerated, ulcerated, withered, inflamed, paralyzed, numbed, or finally killed, but also healed, bound up, made comfortable and fed, and able to enjoy jouissance. These bodies of flesh are attracted to Jesus by an almost natural gravitational pull, and he seems literally to be swarmed by them: they brought to him everybody like that... Surely this is a case of like attracting like, because in the end Jesus ends up as one of these bodies. The one who has become flesh becomes the most famous case of vulnerable, crucified flesh (which is also transformed and transfigured)....

One of the liturgical implications of this understanding of body would be that it expresses and affirms the inclusive character of worship. It is not meant only for the elite or the perfect. The image of the broken body literally opens up the arms of liturgy, stretching out to all of broken humanity. Vosloo (2006:31) calls this stance "an ethos of vulnerable interdependence". Within this form of embodied worship, the suffering of one literally becomes the suffering of all (1 Cor 12:26). In embodied worship the experience of brokenness reminds all who are incorporated that they are in fact part of a larger story, a Eucharistic story - inclusive of broken bodies and a Body. "Sickness makes it impossible to avoid the reality of our bodies. When I am sick, I am not a mind with a suffering body; I am the suffering body. Illness may be the only time that we have the opportunity to discover that we are part of a story that we did not make up" (Hauerwas 1999:29).

In worship, the body is broken. But it is also healed, because the broken Body is absent. Body-liness in a Christian perspective does not only denote crucified flesh, but also the resurrected Body. It speaks of ascension. The broken, but healed (glorified) Body of Christ is present in the body of his church ("Christus als Gemeinde existierend"), but it is also absent, is also in heaven. This absence of the present body of Christ affirms the reality of our healing, even if reality indicates the contrary. This calls for celebration - of the present, absent Body of Christ.

The sacraments, and the Eucharist in particular, remind us in the first instance that we are bodies, and that the act of faith also does not bypass or devaluate the existential reality of our sensory 
body-liness. Höhn (2003:248) puts it this way: "Theologie und Praxis der Sakramente sind dabei an erster Stelle zu nennen, an der die Sinnenhaftigkeit und Sinnlichkeit des Glaubens ebenso manifest wird wie sein Existenzbezug”.

But we are reminded of more than just our bodies. We are reminded of another Body - present in the embodied church, and absent in glorification. It is exactly in celebrating the Eucharist that we are reminded of this eschatological ${ }^{4}$ tension between presence and absence, or indeed presence of absence. Mitchell (2005:143) states that "the eucharist is thus 'the paradigmatic figure of this presence-of-the-absence of God outside of which faith would no longer be faith'... presence and absence form one ambivalent reality".

In the Eucharist we see, hear, taste, feel and smell the tension of the "already" and the "not yet", the tension of faith in the present, absent God. That which is laid out on the Eucharist table is eaten, but never fully digested; it is given to us, but never falls completely into our grasp; it is broken, but never destroyed; shared, but never used up; handed out to all, but never exhausted; in essence, it is presence, but simultaneously, absence. The apt words of Mitchell (2005:151) come to mind: "It is our task, then, to embrace the iconic gift of Christ's Eucharistic presence trembling with joy and courage, while never forgetting our doubt and fear. We must learn to recognize the presence of the absence, the truth of that Stranger who, blessing and breaking bread in the lonely outposts of our lives, comes as close as our breath and body, only to vanish from our sight”.

This trembling embracement of the presence-in-absence of the Eucharistic Christ could indeed be called fides quaerens corporalitatem.

4 The sacraments, and the Eucharist in particular, of course have more dimensions than just the eschatological. The meaning of the Eucharist could, for instance, be described in terms of categories of time, as expression of God's acts in the past, present and future. In this regard Gerd Theissen (2004:352360) summarises the multi-layered meaning of the Eucharist in ten theses. One could say that a type of condensation of the times takes place in the Eucharist: the past is presented in such a way that a yearning for the future is created, a future that, however, continuously breaks through into the present (cf Van Wengen-Shute 2003:101; also Wainwright 1983:131). 


\section{Consulted literature}

Begbie, J S 2003. Voicing Creation's Praise. Towards a Theology of the Arts. New York: Continuum (T \& T Clark).

Bonhoeffer 1998. Sanctorum Communio. Dietrich Bonhoeffer Works. Vol 1. Minneapolis, Minn: Fortress.

-, 2002. Letters and Papers from Prison. London: Fontana Books.

Calvin, J 1973. Institutes. Florida: Mac Donald Publishing Company.

Caputo, J D 1993. Against Ethics. Contributions to a Poetics of Obligation with Constant Reference to Deconstruction. Bloomington and Indianapolis: Indiana University Press.

-, 2006. The Weakness of God. A Theology of the Event. Bloomington and Indianapolis: Indiana University Press.

Cilliers, J H 2007. Binne die kring-dans van die kuns. Die betekenis van estetika vir die gereformeerde liturgie. Stellenbosch: Sun Press.

Dingemans, G D J 1996. Manieren van Doen. Inleiding tot de studie van de Praktische Teologie. Kampen: Kok.

Dunn, J D G 1998. The Theology of Paul the Apostle. Grand Rapids, Michigan/ Cambridge, U.K.: Eerdmans.

Guardini, R 1997. The Spirit of the liturgy. New York: Crossroad.

Hauerwas, S 1998. Sanctify them in the Truth. Holiness Exemplified. Nashville: Abingdon.

-, 1999. The Sanctified Body: Why Perfection Does Not Require a "Self" in Powell, S M and Lodahl, M E (eds), Embodied Holiness. Toward a Corporate Theology of Spiritual Growth. Illinois: InterVarsity Press, 19-38.

Höhn H J 2003. “Zeig's mir!” Theologie zwischen Ethik und Ästhetik in Katechetische Blätter. Zeitschrift für Religionsunterricht, Gemeindekatechese, Kirchliche Jugendarbeit, 128(4), 242-248.

Jordan, I, Tucker, F 2002. Using indigenous art to communicate the Christian message in Evangelical Missions Quarterly, 38(3) July, 302-309.

Louw, D 2001. Creative hope and imagination in a Practical Theology of aesthetic (artistic) reason. 4th International Academy of Practical Theology. Quebec International Conference, Canada, 14-20 May 1999 in Ballard, P \& Couture, P (eds), Creativity, imagination and criticism: the expressive dimension in Practical Theology, 91-104. Cardiff: Cardiff Academic Press.

-, 2008. Cura Vitae. Illness and the healing of life in Pastoral Care and Counselling. Wellington: Lux Verbi.BM.

Lukken, G 1990. Liturgie en Zintuiglijkheid, Over de betekenis van lichamelijkheid in de liturgie. Hilversum: Gooi \& Sticht.

McFague, S 1987. Models of God. Theology for an Ecological, Nuclear Age. Philadelphia: Fortress. 
McGann, M E 2002. Timely wisdom, Prophetic challenge: Rediscovering Clarence R J Rivers' vision of effective Worship in Worship 76(1) January, 2-24.

Meyer-Blanck, M 2005. Theatralisch inspirierte Liturgie in Pastoral Theologie. 94(4), 134-145.

Mitchell, N D 2005. Mystery and Manners: Eucharist in Post-Modern Theology in Worship 79(2), March, 130-151.

Orth, P 2003. Ästhetischer Religionsunterricht. Katechetische Blätter. Zeitschrift für Religionsunterricht, Gemeindekatechese, Kirchliche Jugendarbeit, 128(4), 249-254.

Ramose, M B 1999. African Philosophy through Ubuntu. Harare: Mond.

Schleiermacher, F 1989. The Christian Faith [Trans HR Mackintosch and JS Stewart]. Edinburgh: T \& T Clark.

Sellmann, M 2003. Mode - das Äussere zählt! Katechetische Blätter. Zeitschrift für Religionsunterricht, Gemeindekatechese, Kirchliche Jugendarbeit, 128(4), 259-263.

Shutte, A 1993. Philosophy for Africa. Rondebosch, South Africa: UCT Press.

Theissen, G 2004. Der Sinn des Abendmahls. Pastoral Theologie 93(9) September, 352-360.

Van der Leeuw, G 1949. Sacramentstheologie. Nijkerk: Callenbach.

Van Erp, S 2003. Fides quaerens imaginem. Esthetica als fundamentele theologie: geloof op zoek naar beelden in Tijdschrift voor Theologie 43, 1539.

Van Wengen-Shute, R 2003. Time and Liturgy in George Herbert's The Temple in Theology, March/April 2003, 98-107.

Vosloo, R 2006. Body and Health in the Light of the Theology of Dietrich Bonhoeffer. Religion and Theology. A Journal of Contemporary Religious Discourse. Volume 13(1), 23-37.

Wainwright, G 1983. The Ecumenical Moment. Crisis and Opportunity for the Church. Grand Rapids: Eerdmans.

Wepener, C J 2002. The object and aim of multidisciplinary liturgical research in Scriptura 17(2), 1-15.

Wheeler, G 2003. Revisiting the Question of the use of Visual Art, Imagery, and Symbol in Reformed Places of Worship in Vischer, L (ed), Christian Worship in Reformed Churches past and present. Grand Rapids: Eerdmans, 348-370.

White, J F 1989. Protestant Worship Traditions. Louisville: Westminster/John Knox. 